\title{
Richard Green
}

Richard Green, a computational biologist at the University of California, Santa Cruz, was one of 118 young researchers to win a US\$50,000 two-year research fellowship from the Alfred P. Sloan Foundation, a philanthropic institution based in New York City. Green tells Nature how the fellowship will help to distinguish his work from that of his mentors.

\section{Why did you choose computational biology} over bench work?

I found that the cycle of determining whether an experimental idea is good or bad was much faster with a computer than a pipette - which is a big deal for someone like me, with many varied interests I hope to explore.

\section{What is the market like for computational biologists?}

There is a huge demand, but not that many people who marry a deep understanding of molecular biology with the ability to think in terms of algorithms. It's really a seller's market for people with these skills. As a result, I'm in the enviable position of getting to pick and choose what I want to work on. It's important to note that there is not some new discipline called 'computational biology'; it's really a third entity that combines biology and computational ability. I suggest that young scientists become specialists in both disciplines.

Has the prolific generation of genomics data altered career expectations?

The bar has been raised: the sequencing and basic analysis of a genome is no longer an automatic paper in Science or Nature. But that's a good thing. We have to be more creative; for example, species' genomes can be compared to gain an evolutionary perspective of the transition to multicellularity.

\section{How did you navigate your postdoc?}

If grad school is where a young scientist's ship is assembled, then the postdoc is the launching pad where you take off - or not. I had a great set of projects as a graduate student in Steven Brenner's lab at the University of California, Berkeley. One of my last projects was investigating how alternative gene splicing evolves in flies. As a postdoc, I wanted to ask the next obvious question: how quickly did alternative splicing evolve between chimps and humans? I was fortunate that my adviser introduced me to Svante Pääbo, director of evolutionary genetics at the Max Planck Institute for Evolutionary Anthropology in Leipzig, Germany.

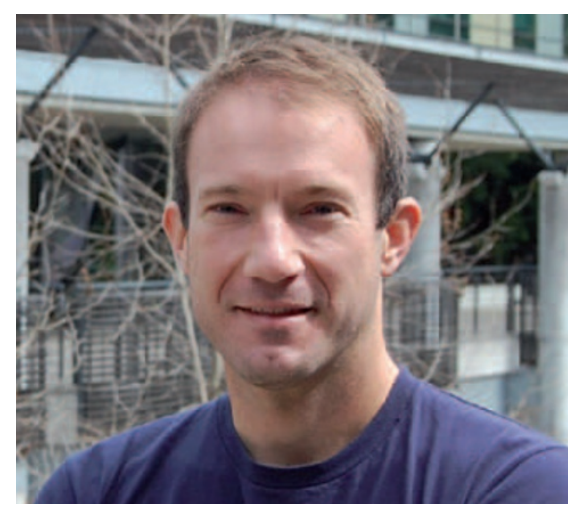

Having your boss put you on these top researchers' radar screens is incredibly helpful.

How did you get involved with the Neanderthal genome sequencing project?

Blind luck. Shortly after I arrived, Svante was experimenting with a new shotgun sequencing method before applying it to the precious few samples of Neanderthal DNA extracted from bone remnants. He wanted someone to align the sequences of ancient cave-bear DNA derived using this method to other genome sequences in the database - something I could easily do, so I volunteered to impress my boss. Those alignments proved that the method worked. We then applied it to some of our best Neanderthal extracts, and Svante encouraged me to work on this. The Neanderthal project was such an incredible opportunity that I left the alternative splicing to the side.

\section{Did that cause problems with funders?}

A little. I dutifully told my funders about my change in focus - and I had to reapply under a different programme to avoid getting my funding pulled. It was unfortunate that the funders didn't immediately see that this was a once-in-a-lifetime project and that I was perfectly positioned to do it.

\section{Is your work riskier than most scientists'?}

Maybe. One of the hallmarks of my research is that I do many things. This traditionally has been viewed as a weakness. If you have many areas of expertise, they can erode one another in people's perceptions. I want to use my expertise to move different fields forward; for example, sequencing the alligator genome will offer new insight into developmental as well as evolutionary biology.

\section{LEGISLATION}

\section{Gender equality bid}

For the third time since 2008, US legislators have introduced a bill in the House of Representatives aimed at tackling gender inequalities in research. Eddie Bernice Johnson (Democrat, Texas), the sponsor of the bill, argues that the paucity of women in fields such as physics constitutes a competitive disadvantage for the United States. The bill would compel all US funding agencies to extend grants or fund temporary workers when researchers need time off to care for their families. The first try at the legislation died in committee in 2008; the second, last year, hitched it to another bill from which it was stripped before passage. Progress depends on the House Committee on Science, Space, and Technology and its chairman, Ralph Hall (Republican, Texas), who will decide whether the bill will be considered.

\section{BIOMEDICAL FUNDING}

\section{Disheartening cuts}

The effects of a US budget crunch could drive young scientists into other jobs, warns Francis Collins, director of the National Institutes of Health (NIH). At a Washington DC panel on 15 March, Collins noted that NIH grant success rates have slid from $25-30 \%$ to $20 \%$ and below in the past 4 years, owing to cuts. "Are these people going to keep banging their heads against the wall? Or are they going to find some other way to make a living?" said Collins at the talk, which was presented by Research!America, an advocacy group in Alexandria, Virginia. Few legislators understand the importance of investing in research, said panelist and former US representative Mike Castle. "Agencies need to get their story out," he said.

\section{NASA}

\section{Agency woos women}

NASA has built a website to boost women's and girls' familiarity with the agency, raise their interest in working there and increase recognition of female contributions to aeronautics. The site, http://women.nasa.gov, was launched on 16 March and gives glimpses into the work lives and accomplishments of female astronauts, researchers and engineers through videos and essays. A careers page provides links to job openings, including graduate and postdoc fellowships. A NASA spokeswoman says that the agency is trying to change the perception that it is male-dominated. 